\title{
Bekçilerin Toplumsal Rolleri: Savunulabilir Mekân Teorisinden Hareketle Medya Temsilleri Üzerine Bir Değerlendirme
}

\author{
Social Roles of Night-Watchmen: An Assessment of Media Representations Based on \\ Defensible Space Theory
}

\author{
Dr. Öğr. Üyesi Aykut ÇALIŞKAN ${ }^{1} 1$
}

\begin{abstract}
$\ddot{O} z$
Güvenlik hizmetlerinin asayişi temin ve halka yardım vazifelerinde yerel düzlemde sorumluluk üstlenen ve kentlerin en küçük mahalli birimlerinde görev alan çarşı ve mahalle bekçileri Türk toplumun geleneksel bir toplumsal grubudur. Çarşı ve mahalle bekçiliği süregeldiği farklı tarihsel dönemlerde varlığını kurumsal açıdan her zaman korumuş, ancak suçun önlenmesi noktasında görev anlayışı ve sahadaki uygulamaları dönemsel şartların beklentilerine göre değişikliğe uğramıştır. Bununla beraber modern toplum anlayış1 sosyalleşme süreçlerine atfettiği rol nedeniyle psiko-sosyal dürtüler arasında yer alan güven duygusunun toplumun üyeleri arasında yaygınlaşmasına da odaklanmıştır. Bu çalışma; çarşı ve mahalle bekçilerinin görev tanımlarının düzenlendiği ve 2020 yılında yürürlüğe giren 7245 sayılı kanun kapsamında çarşı ve mahalle bekçilerinin toplumsal rolünü medya temsilleri üzerinden incelemektedir. Suç önleme faaliyetleri çerçevesinde hazırlanan medya temsillerini savunulabilir mekân teorisinin öncelliğinde post pozitivizm bakış açısıyla nitel araştırma yöntemiyle analiz etmektir. Bu çerçevede 2016-2020 yılları arasında haber sitelerinin "Çarşı ve Mahalle Bekçisi”, "Suç İstatistikleri” ve "Suç Önleme” kavramları üzerinden yapılan tarama sonuçları içerik analizine tabi tutulmuştur. Bekçilerin suç önlemeye dönük katkıları asayiş uygulamaları üzerinden makro veriler üzerinden anlatılırken, toplumsal iş birliği ve duyarlılığın gelişiminde başarılı faaliyetlerin belirtildiği anlaşılmış, ancak toplum destekli suç önleme faaliyetlerine dair sağlıklı bir veri elde edilememiştir. Çarşı ve mahalle bekçilerinin sorumlu olduğu mahallelerde suç önlemeye dair faaliyetlerinin mikro ölçekte daha belirgin bir şekilde ifade edilmesi ve suç olaylarının çözümlenmesinde toplum desteğinin katkısının yansıtılmasının faydalı olacağı sonucuna varılmıştır.
\end{abstract}

Anahtar Kelimeler: Kent sosyolojisi, mekân, medya, suç önleme, bekçi

Makale Türü: Araştırma

\begin{abstract}
The night-watchman is a traditional social group of the Turkish society, who take responsibility at the local level in the duties of ensuring the security. Night-watchman has always preserved its existence institutionally in different historical periods, however, the understanding of duty and its practices in the field have changed according to the expectations of the periodic conditions in terms of preventing crime. Also, the understanding of modern society has also focused on the dissemination of trust emotion among the psycho-social drives among the members of the society due to the role it attributes to socialization processes. This work: it examines the social role of night-watchman through media representations within the scope of the law number 7245, which regulates the job descriptions of the night-watchman and entered into force in 2020. It is to analyze the media representations prepared within the framework of crime prevention activities with the qualitative research method with the perspective of post-positivism, with the priority of defensible space theory. In this context, the results of the screening of news sites on the concepts of "Night-watchman", "Crime Statistics" and "Crime Prevention" between 2016- 2020 were subjected to content analysis. While the contributions of the guards towards crime prevention are explained through macro data through public order practices, it has been understood that successful activities in the development of social cooperation and sensitivity are indicated, but no reliable data on communitysupported crime prevention activities have been obtained. It was concluded that in the neighborhoods where
\end{abstract}

${ }^{1}$ Dokuz Eylül Üniversitesi, Edebiyat Fakültesi, aykut629aykut@hotmail.com.

Atıf için (to cite): Çalışkan, A. (2021). Bekçilerin toplumsal rolleri: Savunulabilir mekân teorisinden hareketle medya temsilleri üzerine bir değerlendirme. Afyon Kocatepe Üniversitesi Sosyal Bilimler Dergisi, 23(1), 20-36. 
the night-watchman is responsible, it would be beneficial to express the crime prevention activities more clearly on a micro scale and to reflect the contribution of the community support in the resolution of crime.

Keywords: Urban sociology, space, media, crime prevention, night-watchman

Paper Type: Research

\section{Giriş}

Günümüz insanı dış çevreden gelen tehdit ve tehlikelere karşın kendisini ve birlikte yaşadığı diğer insanları koruyabilmek amacıyla büyük çaplı kurumlar üzerinden güvenlik taleplerini karşılama yoluna gitmektedir. Genel asayiş ve güvenliğin sağlanması noktasında kamu kurumları arasında yer alan İçişleri Bakanlığı Türkiye'de bu işlevinin yerine getirilmesinden sorumludur. İçişleri Bakanlığı ve bağlı kuruluşları arasında yer alan Emniyet Genel Müdürlüğü, Jandarma Genel Komutanlığı merkez ve taşra teşkilatları vasıtasıyla kentsel ve kırsal alanda güvenlik hizmetlerini yerine getirmektedir. Büyük ölçekte kurumların teşkilat yapıları mahalli idarelerin en küçük birimi olan mahallere ulaşmakta sadece güvenlik hizmetleri olarak değil, aynı zamanda eğitim, sağlık, yerel hizmetler ve altyapı gibi pek çok gereksinimin karşılanması görevlerini üstlenmektedir.

Güvenlik hizmetlerinin asayişi temin ve halka yardım vazifelerinde yerel düzlemde sorumluluk üstlenen ve kentlerin en küçük mahalli birimleri olan mahallerde görev alan çarşı ve mahalle bekçileri ilk bakışta geleneksel bağlarına benzer nitelikte görev anlayışı sürdürdüğü söylenebilir. Öyle ki Çarşı ve Mahalle Bekçiliği süregeldiği farklı tarihsel dönemlerde varlığını kurumsal açıdan her zaman korumuş, ancak suçun önlenmesi noktasında görev anlayışı ve sahadaki uygulamaları dönemsel şartların beklentilerine göre değişikliğe uğramıştır. Bununla beraber bekçilik görev olarak modern zamanda ihtiyaç duyulan yerel güvenlik taleplerine kamu güvenliği ve suçun önlenmesi açısından katkı sağlarken, özellikle güvenlik hizmetlerinde liberal yaklaşımı esas alan ve güvenlik hizmetlerinin özelleşmesi sonucu ortaya çıkan mikro ölçekli özel güvenlik hizmetlerinden sorumluluk, yetki ve kurumsal düzeyde de farklılaşmıştır.

Bu çalışma, 18 Haziran 2020 tarihinde Resmî Gazetede yayınlanan 7245 sayılı Çarşı ve Mahalle Bekçileri Kanunu dikkate alınarak çarşı ve mahalle bekçilerinin genel kolluk kuvvetlerine yardımcı olmak üzere Emniyet ve Jandarma birimleri bünyesinde yer aldığının neşredilmesi bilgisi dâhilinde hazırlanmıştır. Mezkûr düzenlemeyle çarşı ve mahalle bekçilerine halka yardım, önleyici ve koruyucu görevler, durdurma ve kimlik sorma, adli görevler, zor ve silah kullanma ile genel kolluk birimlerine yardımcı olma gibi görev ve yetkiler verilmiştir.

Çarşı ve mahalle bekçilerinin temel asayiş hizmetlerinin sağlanması açısından yetki sınırları hali hazırda görev yapan genel kolluk kuvvetleriyle benzer bir örüntüye kavuşturulmuş, mahalli birimlerde yaşanan suç olaylarına ilk elden müdahale etmeleri sağlanmış, pro-aktif suç önleme süreçlerinde kültürel doku günümüzün değişen koşullarına göre yeniden uyarlanmıştır.

Bu amaçla çarşı ve mahalle bekçileri tarafından suç önlemeye dönük yapılan faaliyetlerin medya içerikli veriler üzerinden temsilleri ve topluma bakan yansımaları diğer toplumlarda uygulanılan ve yerel güvenlik anlayışıla bireye sorumluluk yükleyen Savunulabilir Mekân Teorisi'nden hareketle anlaşılmaya çalışılmıştır. Geleneksel motifleri taşıyan bekçilik kavramının modernleşme süreci tarihsel süreç içerisinde ifade edilirken, bekçilik unvanın tasviri ve sahaya dönük katkıları 7245 sayılı mevzuat uyarınca incelenmiştir.

$\mathrm{Bu}$ bağlamda yapılan araştırma geçmiş tarihli kanun düzenlemeleri üzerinden çarşı ve mahalle bekçilerinin geleneksel ve modern anlamda güvenlik hizmetleri bağlamında yeniden değişimini ele alırken, suçun önlenmesi sürecinde görev ve yetkilerini medya temsilleri üzerinden sunumunu nitel araştırma yöntemiyle analiz etmektedir. 


\section{1. Çarşı ve Mahalle Bekçisine Tarihsel Bakıș}

Çarşı ve mahalle bekçilerinin tarihsel süreç içerisinde işlevinin anlaş1labilmesi için gündelik yaşamda önemli yeri olan ve idari açıdan mahalli yönetim birimi olarak nitelendirilen mahallelerin tasviri önemlidir. Gündelik hayat pratiklerinde bireyin gereksinimlerine yön veren ve önde gelen mekânların çarşı veya pazar ile mahalleler olarak isimlendirildiğini bilmekteyiz. Çarşı ve pazar yerleri mal veya hizmetlerin temini ve dağıtımını sağlamakta, mahalleler ise barınma ihtiyacının karşılandığı konutlar ile küçük çaplı işletmelere ev sahipliği yapmaktadır. Temel ihtiyaçların karşılanması bakımından çarşı ve mahalleler sadece fizyolojik gereksinimlerin karşılanmasına da cevaz vermemekte aynı zamanda sosyal yaşamın ilişkilerinin işlendiği ve gündelik yaşamın yoğun geçirildiği alanları bizlere sunmaktadır.

Dolayısıyla bireye mekân sağlama gibi özellikleri haricinde toplumsal bir kimlik edindirme sürecinde yer alan mahalleler bireysel ve kurumsal ilişkilere zemin sağlamaktadır. Osmanlı Devleti'nde mahallerin statüsü; sosyal ve mali ilişkilerinin kontrol aracı olarak tarif edilmektedir (Bayramoğlu, 2008, s.123, Aliağaoğlu ve Uğur, 2016, s.215). Gündelik yaşantının yoğun olduğu bu mekânlarda güvenliğin sağlanarak toplumsal huzurun sağlanması ise asli önem taşımaktadır. Fiziki olarak anlamlandırılan ve sosyal yapının sürdürülebilirliğine olanak tanıyan toplumsal mekânların sağlıklı bir biçimde devamlılığın sağlanabilmesi ise güvenlik ihtiyacının yerel talepler dikkate alınarak çözümlenmesiyle sağlanmaktadır. Bu bağlamda tarihsel süreç içerisinde güvenlik taleplerinin karşılanması noktasında bekçilik kurumunun örneklerinin İngiltere'de görüldügüü anlaşılmaktadır.

Gece Bekçiliği tarihsel süreç içerisinde İngiltere ve Amerika gibi ülkelerde kanunların uygulanması amacıyla bir sistem içerisinde uygulanmıştır. Bekçilerden beklenen görev akşam dokuz ile on gibi saatlerden sonra sabaha kadar devriye gezmeleri ve şüpheli karakterleri incelemeleridir. Bu uygulamaların Avrupa'da XVII. yüzyıla kadar devam ettiği anlaşılmaktadır. Nüfusun artması, dönemin sosyal ve kültürel yaşamının ekonomik ve endüstriyel gelişmelerin etkisiyle değişime uğraması gece bekçiliği görevinin de gerçekleştirilmesini zorlaştırmıştır. Çünkü geceleri ilerleyen saatlere kadar açık olan eğlence yerleri (tiyatro, restoran, dükkân, diğer eğlence yerleri) belirli bir saat sonrasında bireylerin dışarı çıkmamaları yönünde geçmiş dönemlerde uygulanan kararları da değiştirmiştir. Gece bekçiliğinin değişen kentsel yaşamdan etkilenmesi işlevini yitirmesine sebep olmuştur. XVII. yüzyıl sonunda İngiltere' de birçok ev sakininin önceleri sırayla kendileri tarafından yerine getirilen bekçilik görevini bu işi parayla yerine getiren başka bireylere devretmesi ve yükümlülükten kaçması yaygınlaşmıştır. Ancak erken dönem İngiliz tarihinin büyük bölümünde kamu yaptırımlarının ücretsiz ve sıradan insanlar tarafından gerçekleştirildiği kabul edilmektedir. Ceza adalet sisteminde uygulanılan jüri görevi gibi modern kolluk faaliyetlerinin öncesinde herkese düşen rol vatandaşlık görevinin gereği suç önleme faaliyetlerine katılmaktadır (Thornburn, 2010, s.432-433).

Bu nedenle ilerleyen dönemlerde gönüllü olarak savcılık kurumlarının ücret karşıllı̆ında erkek bireyleri devriye hizmetlerinde kullandıkları görülmüştür. 1820'li yıllardan sonra ise artan suç oranları nedeniyle gece bekçileri yerine polislerin işlevsel hal aldığı anlaşılmıştır (Beattie, 2001, s.170-172). Amerika Birleşik Devletleri'nde ilk toplumsal koruma biçimleri ise İngiltere'de geliştirilen uygulamalar ile benzerlik taşımıştır. Baston şehri XVII. yüzyılda gece nöbeti kurulan ilk yerleşim yeri olmasından sonra diğer kentlere de bu sistem yayılmış, yasaların birleştirilmesi ve merkezi otoriterinin etkinliğinin artmasından sonra devlet tarafından yönetilen polis güçlerine dahil edilerek bekçilik uygulamasına son verilmiştir (Plymouth Polis Bölümü, 2020).

Osmanlı Devleti'nde ise koruma ve güvenlik hizmetlerinde mahalle kavramının yeri önemlidir. Suç işleyen bireylerin tespiti ve cezalandırılması, vergilerinin alınması, sosyal kontrolün sağlanması, ihtiyaç duyulan hizmetlerin karşılanması gibi işlevlerin yerine getirilmesi için mahalleler mekân sağlamaktadır (Doğan, 2019, s.258-260). Ayrıca bu mahallerde; sosyal ve fiziki bir birim olmasının yanında birbirlerinin davranışlarından sorumlu, sosyal dayanışma içerisinde beraber yaşayan toplulukların tanımlanması yapılmıştır (Düzbakar, 2003, s.98-99). 
Osmanlı Devleti'nde mahallede yer alan bireyler gündelik yaşamın getirdiği zorunlu faaliyetleri sürdürmekte, genel ahlak ve birlikte yaşamanın kültürel dokusunda yer alan ve yazılı olmayan kuralların mahalle sakinleri tarafindan takip edilmesine de özen göstermektedirler.

Geçmişe dönük uygulamaların Osmanlı Devleti’nde de görüldüğü bekçilik müessesinin başlangıç tarihine dair net bir tarih bilinememektedir (Lévy, 2008, s.138). Bekçiler, öncelerinde mahallelerin bedesten, çarşı ve konakların korunması gibi görevleri üstlenmiştir. Osmanlı Devleti'nin 19 uncu yüzyıl modernleşme çabaları içerisinde bekçilik kurumunun ücret sisteminde değişikliğe gidilmiş, çıkarılan Muvakkat Kanunuyla ücretlerin halktan toplanması yerine belediyeler tarafından belirlenen tutar doğrultusunda halktan karşılanmasına karar verilmiştir. Bekçilik görevi üstlenen kişiler; sorumluluklarında yer alan mahalle sakinlerini tanıyan, kefile bağlanmış, yaşlı ve namuslu kimseler olarak tanımlanmaktadır. Ayrıca görev gereği geceleyin hava karardıktan sonra sorumlu olduğu alanlarda huzur ve güveni sağlama noktasında asayiş hizmetlerinin sürdürülmesinde mahalle sakinlerine hizmet vermiştir. 1914 yılında çıkarılan "Çarş1 ve Mahalle Bekçileri Hakkında Kanun-1 Muvakkat" 1966 yılına kadar uygulanmasına devam edilmiştir. Buna göre kent ve kasabalarda yer alan çarş1 ve mahallerde bekçilerin görevlendirilmesi zorunlu kılınmıştır (Şeker, 2009, s.262-263).

Cumhuriyet döneminde ise var olan bekçilik kurumuna dair düzenlemenin korunduğu görülmekle birlikte 1966 yılında çıkarılan Çarşı ve Mahalle Bekçileri Kanunu'nda yapılan düzenlemeler ile çarşı ve mahalle bekçilerinin ödeme ve giderlerinin İl Özel İdarelerine devredildiği anlaşılmaktadır. Belirtilen yasal düzenlemeye göre çarşı ve mahalle bekçileri polise yardımcı zabıta memuru olarak görevlendirilmiş ve polis karakollarında görev alarak sorumlu oldukları mahallelerin güvenlik ihtiyaçlarını karşılamışlardır. Çarşı ve mahalle bekçileri belirli bir süre sonra yardımcı hizmetler sınıfina dâhil edilmiş ve mahallelerden çekilmişlerdir (Gökçe ve Kulu, 2019, s.155).

Devamında, 8 Mayıs 2008 tarihinde Resmî Gazetede yayınlanan 5757 sayılı kanunla çarşı ve mahalle bekçileri yardımcı hizmetler sınıfından 657 sayılı Devlet Memurları Kanunu'nda yer alan emniyet hizmetleri sınıfına aktarılmıştır. Emniyet hizmetleri sınıfında görev ve yetkileri bağlamında 2559 sayılı Polis Vazife ve Salahiyet Kanunu'na tabi olarak değil de 772 sayılı Çarşı ve Mahalle Bekçileri Kanunu'na göre fiili görevleri devam etmiş, ancak bu süreç içerisinde de fiziki olarak mahallerde görevlerini sürdürmemişlerdir. $\mathrm{Bu}$ süreç içerisinde bekçiler polis merkezlerinde görevlendirmeleri yapılmış, ancak geceleyin güvenlik hizmetleri bağlamında geçmiş dönemlerde beklenilen görevlerini yerine getirmemişlerdir.

Emniyet Genel Müdürlüğü bünyesinde yeniden alım yapılmaya başlanılan 06.04.2016 tarihinden sonra çeşitli dönemlerde çarşı ve mahalle bekçi alımlarında artış gözlemlenmiştir. Bu tarihten sonra belirli aralıklarla alım süreçleri devam etmiş ve 18 Haziran 2020 tarihinde ise yasal mevzuat açısından genel kolluk kuvvetlerine yardımcı olmak üzere 7245 sayılı Çarşı ve Mahalle Bekçileri Kanunu yayınlanmış ve son haliyle yürürlüğe girmiştir (Anadolu Ajansı, 2020).

Şekil 1. Çarşı ve mahalle bekçi sayısının emniyet hizmetleri sınıfı içerisinde görünümü

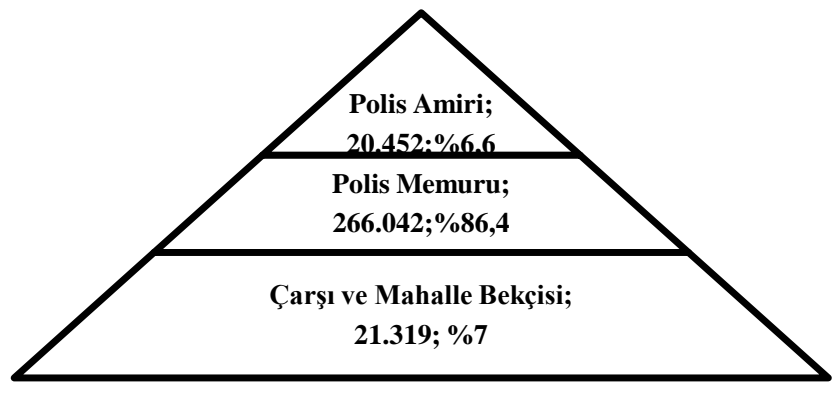

Kaynak: Anadolu Ajans1, 2020 
Bu çerçevede Anadolu Ajansı tarafından 09.04.2020 tarihinde güncel çarşı ve mahalle bekçi sayısına ilişkin bildirilen veriler üzerinden 21.319 kişi olduğu anlaşılmıştır. Toplam 307.813 olan emniyet hizmetleri sınıfı personelinin \%7'sinin çarşı ve mahalle bekçileri olduğu anlaşılmıştır.

\section{Savunulabilir Mekân Teorisi ve Bekçilerin Toplumsal Rolü}

Bilginin anlamlı hale getirilme sürecinde araştırma çerçevesinde sunulan bilgi toplama araçlarının kıymetlendirilmesi ve olguların ele alınış şekli öncelikle metodolojik kaygılar özelinde epistemolojik bir tartışma alanı içerisinde kendisine yer bulur. Tümdengelimsel bir yaklaşım mevcut olguların sosyal gerçekliği inşasında kuramsal bakış açısını bizlere sunarken, farklı uygulamaların toplumlar üzerinden inşasında sistematize edilmiş önermeleri benzer işlevlere sahip örüntüler içerisinde sayıltılarıyla test edilmesine imkân sağlar. Bu bakış açısından yola çıkarak yapılan araştırma tümdengelimsel bir teknikle anılan kuramın sayıltılarını test etmek yerine, tümdengelimsel bir akıl yürütme tekniğiyle öncelikle belirtilen kuramın bakış açısını ele almaktadır. Çalışmada nitel bir araştırma öncesi epistemolojik açıdan postpozitivizm bakış açısıyla tümevarımsal bir akıl yürütme tekniği geliştirilmesinde savunulabilir mekân teorisinin bakış açısından istifade edilmiştir.

Bu noktada gündelik hayatın güvenlik ihtiyaçları kamusal bir hizmet anlayışıyla Türkiye özelinde çarşı ve mahalle bekçileri tarafindan gerçekleştirilmektedir. Bununla beraber modern toplum anlayışı sosyalleşme süreçlerine atfettiği rol nedeniyle psiko-sosyal dürtüler arasında yer alan güven duygusunun toplumun üyeleri arasında da yaygınlaşmasına odaklanmaktadır. Metropol ve kent yaşamının göç, nüfus artışı, dikey yapılanmaların artan yönde ivmelenmesi ve farklı kültürel özellikleri barındıran bireylerin çeşitliliğinde yaşanan artışlar nedeniyle güvenlik ihtiyaçları özelinde bireye yüklenilen sorumluluk ve ödevlerde de değişim yaşanmıştır. Bu çerçevede temel güvenlik ihtiyacının toplum üyeleri arasında yapılı ve fiziki çevre üzerinde inşa edilmesine yönelik Oscar Newman tarafından sunulan Savunulabilir Mekân Teorisi'nin kuramsal yapısı incelenmek istenilmiştir.

Suç önleme çalışmaları kapsamında asıl mesleği mimarlık olan Oscar Newman (1972) tarafından geliştirilen savunulabilir alan yaklaşımı dört temel tasarım unsuru üzerine şekillenmiştir. Kuram suçun önlenmesinde bölgecilik, doğal gözetleme, imaj ve çevre özelliklerinin kentsel yapı dizaynında önemli olduğunu savunmaktadır (Newman, 1972, Kaya ve Cicerali, 2018, s.104). "Savunulabilir Alan: Şehir Tasarımıyla Suç Önleme” isimli kitabında kuramını izah eden Oscar Newman sosyal birliği sağlayacak şekilde geliştirilen sosyal çevrelerin merkezi otoritenin katkısıyla beraber suçun önlenebileceği tezini savunmuştur (Donnelly, 2010, s.3).

Kuram; şehirlerde ve yerleşim yerlerinde suça yönelik geliştirilebilecek fiziki ve estetik düzenlemeler yoluyla yerleşim yerlerinin daha güvenilir hale geleceğini belirtmektedir. Ayrıca, çevre planlamaları açısından kentlerde yapılacak sistematik düzenlemeler ile birlikte bölgesel hâkimiyet ve toplumsallık duygusuyla hareket eden insanların güvenilir bir çevre oluşturulmasına katkı sağlayacağı ifade edilmiştir (Koca ve Erkan, 2019, s.171-172). Fiziksel çevreye dair uygulamaların çevre sakinleri tarafından bireysel performans ile buluşması durumunda rasyonel tercih bağlamında hareket eden suçluların ise engellenebileceği düşüncesi kuramın en belirgin açıklaması olarak ortaya çıkmaktadır (Newman, 1996, s.9).

Kentlere dair tasarım unsurlarını incelediğimizde bölgecilik özelliği; mekânların suçların önlenmesine yönelik inşa edilme sürecinde bölgede yaşayan sakinlerin teşvik edilmesi ve mahallede yaşamayan yabancıların fark edilmesi anlamında kullanılmaktadır. Gözetleme özelliği ise yaşanılan yerlerin kolay bir şekilde takip edilmesine olanak sağlayacak şekilde tasarlanması olarak ifade edilmektedir. İzlenim özelliği binaların ve yerleşim yerlerinin birbirinden farklı olmayacak şekilde belirli bir imaja ve görüntüye sahip olması şeklinde açıklanırken, dışarıdan gelen yabancıların binaların fiziki özellikleri ile ilgili ayrımda bulunmaması durumu tasvir edilmektedir. Bu çerçevede etiketlenmeyen yerleşim yerlerinde suçun önlenmesi yerleşim yeri 
sakinleri açısından daha kolay bir hale gelmektedir. Çevre özelliği ise; yaşanılan yerin civarında bulunan yaşam alanlarına ilişkin olumlu veya olumsuz imajlardan etkilenerek bir süre sonra bu yerlerin yakınında bulunan malum yerler ile ilişkilendirilmesi sonucunda oluşan algının suçun oluşumuna ortam sağlanabileceğini vurgulamaktadır (Newman, 1973, s.50). Savunulabilir mekân teorisi özetle yerleşim yerlerinin sosyal birlikteliğine önem atfetmesi ve suçun önlenmesi kapsamında yerleşim yerlerinde yaşayan bireylere gözetim ve takip etme olgusu üzerinden verilen ödev ile yapılması gereken bir dizi faaliyetlerin önemine dikkatleri çekmektedir.

Çarşı ve mahalle bekçiliği ise mahallelerde suç önlenmesi sorumluluğunu sürdürmekte ve mahalle sakinlerinin güvenlik alanında ihtiyaç duyduğu hizmetlerin yerine getirilmesinde resen veya gelen şikâyet ve bilgiler doğrultusunda suçun olmadan önce önlenmesi açısından görev üstlenmektedir. Bunun yanı sıra tarihsel süreç içerisinde etkinliği ve sahada olan görünürlüğü dönemsel koşullara ve politik tercihlere göre değişim göstermiştir.

Çarşı ve mahalle bekçiliği Türkiye özelinde Oscar Newman tarafindan 4 temel sacayağı üzerine kurgulanan teorinin fiziki unsurlar harici insan kaynağının temeline katkı sağlayan bir konumda yer almaktadır. Bu çerçevede mahalle sakinleriyle birlikte güvenlik talepleri nezdinde suç önleme, oluşan suça unsurlarıyla birlikte müdahale etme gibi görevleri bulunan ve yardımcı kolluk birimi olarak görev yapan bekçilerinin durumsal açıdan rolünün aktarımı önem taşımaktadır. 7245 sayılı kanun kapsamında suç önleme faaliyetlerinde görev üstlenen çarşı ve mahalle bekçilerinin görev tanımları hukuki açıdan yeni düzenlenirken, toplumsal boyutuna yönelik durumu ise ilerleyen kısımda medya temsilleri üzerinden değerlendirilmiştir.

\section{7245 Sayılı Kanun Kapsamında Çarşı ve Mahalle Bekçilerinin Suç Önlemedeki Sorumlulukları}

Genel kolluk kuvvetlerine yardımcı olmak üzere görevlendirilen çarşı ve mahalle bekçilerinin görev ve yetkilerinin düzenlendiği yasal mevzuatın son hali 18 Haziran 2020 tarihinde yürürlüğe girmiştir. Bu çerçevede mülga edilen 772 sayılı Çarşı ve Mahalle Bekçileri Kanunu'nun üçüncü maddesi kapsamında görevleri sıralanırken; görevlerin yürürlükten kaldırılan yasal mevzuata göre acele ve zaruri hallerde olan görevleri, genel kolluk kuvvetlerine yardım yönünden olan görevleri, istirahat, sağlık ve selameti sağlamak bakımından görevleri olarak düzenlendiği anlaşılmıştır.

Diğer taraftan 7245 sayılı güncel mevzuatta ise görev ve yetkilerinin adli veya idari görev olarak ayrıldığı anlaşılmış, çalışma kapsamında suçun önlenmesine yönelik değerlendirilen idari görevlerinin ise halka yardım, önleyici ve koruyucu görevler, durdurma ve kimlik sorma gibi görevlerden oluştuğu görülmüştür. Adli görevleri ise yürürlükte olan mevzuatta ayrı bir madde kapsamında düzenlenmiştir. Böylece çarşı ve mahalle bekçilerinin görev tanımlarının içeriğinde suç sonrası tanımlanan adli görevler ile suç öncesini kapsayan idari görevler yönünden ayrıma gidildiği tespit edilmiştir.

Tablo 1. Önleyici görevler karşılaştırma cetveli

\begin{tabular}{|c|c|}
\hline $\begin{array}{l}\text { Mülga } 772 \text { Sayılı ÇMB Kanunu } \\
\text { Resmî Gazete Tarihi: 22/07/1966 }\end{array}$ & $\begin{array}{l}7245 \text { Sayılı ÇMB Kanunu } \\
\text { Resmî Gazete Tarihi: 18/06/2020 }\end{array}$ \\
\hline $\begin{array}{l}\text { MADDE } 3 \text { - } \\
\text { A) Genel kolluk kuvvetlerinin derhal } \\
\text { müdahalesine imkân bulunmayan acele ve zaruri } \\
\text { hallerdeki görevleri, } \\
\ldots \\
\text { B) Genel kolluk kuvvetlerine yardım yönünden } \\
\text { görevleri, } \\
\ldots \text { C) Mahalle sakinlerinin istirahat, sağlık ve } \\
\text { selametini sağlamak bakımından görevleri. }\end{array}$ & $\begin{array}{l}\text { "Halka Yardım Görevi } \\
\text { MADDE } 5 \text { - } \\
\text {.. } \\
\text { "Önleyici ve Koruyucu Görev ve Yetkiler } \\
\text { MADDE } 6 \text { - } \\
\text {.. } \\
\text { MArdurma ve Kimlik Sorma } \\
\text { MADDE } 7 \text { - }\end{array}$ \\
\hline
\end{tabular}


Çarşı ve mahalle bekçilerinin önleyici kapsamda yer verilen görevlerinin madde başlığ1 olarak mülga kanuna kıyasla durdurma ve kimlik sorma, önleyici ve koruyucu görev ve yetkiler bakımından değiștiği görülmüştür. Geleneksel olarak Osmanlı Devletinden beri var olan ve Cumhuriyet döneminde de devam eden önleyici ve koruyucu tedbirlerinin geçerliliğini koruduğu görülürken ilave olarak yeni düzenlemeyle durdurma, kimlik sorma, yoklama ve kontrol yetkisinin yasa koyucu tarafindan eklendiği anlaşılmaktadır.

Suç önleme kapsamında çarşı ve mahalle bekçilerinin devriye hizmeti yürütmesi, konut, iş yeri ve araçlarda yer alan malların sahipleri tarafindan noksan görülen eksikliklerin tamamlatılması, kişilerin can, ırz ve malına yönelik saldırı ve tehditlerin önlenmesi, uyuşturucu, kumar ve fuhuş gibi suçlara dair tespitlerin genel kolluk kuvvetlerine bildirilmesi olarak görevleri sıralanmıştır. Çarşı ve mahalle bekçilerinin geçmiş dönemlerde süregelen ve toplum tarafından talep edilen suç önlemeye dönük hizmet beklentisinin yerine getirilmesi noktasındaki görevinin halen geçerliliğini koruduğu anlaşılmıştır. Ayrıca, anlık olaylara müdahaleyi kolaylaştıran durdurma ve kimlik sorma gibi yetkilerin yasa koyucu tarafindan yeni düzenlemede yer verildiği tespit edilmiştir.

Bu bakımdan güncel mevzuat değişikliği süregelen görev tanımlarında benzer bir tanımlama ihtiva ederken, mevcut düzenlemede yapısal yönden farklılaşmaya ve değişikliğe gidilmediği görülmüştür. Durdurma, kimlik sorma gibi yetkiler ise suç önleme faaliyetlerinde suça başvuran bireylerin tespit edilmesi, yakalanması gibi koruyucu tedbirlere başvurulmasında hukuka uygun olması durumunda görevinin tabiatı gereği fiziki açıdan ön şart niteliği taşıyan işlemler olarak yeni düzenlemede yer verildiği görülmüştür.

Bununla beraber, adli makamlar tarafindan ilgili kanunun amir hükmü gereği kolluk birimlerine suç sonrası araştırma süreçleri dahilinde maddi gerçeğin ortaya çıkarılabilmesi amacıyla verilen emir çerçevesinde suçun soruşturulması kapsamına takip edilen adli işlemler ise şüphe kavramının ağırlığıyla ilişkili, temel bir hakkın hüküm kesinleşmeden önce sınırlanmasını sağlayan ve koruma tedbirleri olarak nitelendirilen işlemlerdir. Tablo 1'de yer verilen görev tanımlarından anlaşılacağı üzere çarşı ve mahalle bekçilerinin adli görevlerinin genel kolluk personelinden ayrıldığı, ziyadesiyle idari yönü ağır basan görev ve yetkilerinin mülga kanuna göre geçerliliğini koruduğu anlaşılmıştır. Bekçilerin adli görev ve yetkilerinin ise suçun işlenmesi esnasında gecikmesinde sakınca bulunan hali tanımlayan ve işlenen suça müdahale edilmesini sağlayan görev ve yetkileri kapsadığ 1 görülmüsstür².

5271 sayılı Ceza Muhakemesi Kanunu'nda yer verilen adli arama, gözaltı, el koyma gibi adli bir olayın devamı niteliğinde suçun delil ve unsurlarını ortaya çıkaran koruma tedbirleri ise suçun fail ile eşleştirilmesine imkân tanıyan ve adli emir gerektiren koruma tedbirleridir. Başka bir anlatımla, kolluk birimleri tarafindan yerine getirilen görev ve yetkiler yasal mevzuatın öngördüğü yetki sınırları içerisinde gerçekleştirilen, yasal dayanağının belirlediği usul ve esaslara göre gerçekleştirilen hukuki işlemlerdir.

Kolluk birimlerine yasa koyucu tarafından önleyici kolluk faaliyetleri kapsamında verilen durdurma ve kimlik sorma yetkisi ise içeriği gereği makul bir sebep gerektiren, fiziki açıdan temas edilmesini mümkün kılan ve göreli olarak koruma tedbirlerinden ayrılan hukuki bir işlemdir. Yardımcı kolluk birimi olarak hukuki statüsü verilerin ve hiyerarşik düzen içerisinde konumu belirlenmiş olan çarşı ve mahalle bekçilerinin sorumlu oldukları alanlarda koruma görevlerini yerine getirirken durumundan şüphe ettikleri ve bunu hukuken gerekçelendirebildikleri kimselere durdurması gerektiğinden dolayı önleyici kolluk faaliyeti yetkisinin çarşı ve mahalle bekçilerine verildiği değerlendirilmektedir³.

Dolayısıyla 7245 sayılı kanunun suçun önlenmesi açısından çarşı ve mahalle bekçilerinin görevlerini düzenleyen ve mülga edilen kanunun devamı kapsamında benzer görev ve yetkilere

\footnotetext{
2 İlgili açıklamaya ilişkin 7245 sayılı Çarşı ve Mahalle Bekçileri Kanunu'nun 8. maddesine bakılabilir.

${ }^{3}$ İlgili açıklamaya ilişkin 7245 sayılı Çarşı ve Mahalle Bekçileri Kanunu’nun 7. maddesine bakılabilir.
} 
yer verdiği görülmektedir. Bunun yanında yapılan işlemin hukuki açıdan tüm boyutlarıyla dayanağının oluşturulması noktasında durdurma ve kimlik sorma yetkisiyle de görülen ihtiyacın düzeltilmesi yoluna gidildiği anlaşılmıştır. Çalışma kapsamında ilgili mevzuat hükümleri uyarınca çarşı ve mahalle bekçilerinin geçmiş dönem suç önlemeye dönük görevleriyle benzer işleve sahip olduğu görülmektedir.

\section{Araştırmanın Yöntemi}

Çalışmada nitel araştırma yöntemi esas alınarak veri toplama teknikleri arasında yer alan yazılı doküman inceleme tekniği kullanılmıştır. Bu amaçla çarş1 ve mahalle bekçilerinin yeniden alımlarının yapılmaya başlandığ 1 2016-2020 yılları arasında haber sitelerinin "Çarşı ve Mahalle Bekçisi", "Suç İstatistikleri" ve "Suç Önleme" kavramları üzerinden yapılan tarama sonucu elde edilen yazılı dokümanlar içerik analizi yöntemiyle analiz edilmiştir. Çalışmada kullanılan soru cümleleri Tablo 2'de belirtilmiştir. Temaların görselleştirilmesinde Microsoft Excel programından istifade edilmiştir.

Tablo 2. Araştırma soru cümleleri

\begin{tabular}{cl}
\hline S.N. & \multicolumn{1}{c}{ Araştırma Soruları } \\
\hline 1 & Yazılı dokümanlarda çarşı ve mahalle bekçilerinin sosyal rolüne ilişkin vurgulanan \\
& kavramlar nelerdir? \\
2 & Çarşı ve mahalle bekçilerinin hangi suçları önlemede öne çıktığı görülmektedir? \\
3 & Çarş1 ve mahalle bekçilerince gerçekleştirilen başarılı faaliyetler nelerdir? \\
\hline
\end{tabular}

Çalışma; topluma bilgi verme işlevinden sorumlu medya içeriklerini suç önleme kavramı üzerinden nitel araştırma yöntemi esasıyla analiz etmektir. Metodolojik açıdan tercih edilen bu yaklaşım hukuki düzenlemeyle görev tanımlarının yeniden hüküm altına alınan çarşı ve mahalle bekçilerinin medya temsilleri üzerinden kamuoyuna sunumunu postpozitivizm bilgi edinilmesi tekniğiyle tümevarımsal bir bakış açısıyla irdelemektir. Bu nedenle yerel güvenlik taleplerinde birey ve toplum odaklı suç önleme anlayışını benimseyen "Savunulabilir Mekân Teorisi" nin sunumu dikkate alınarak, bu kuramın insan kaynağı açısından dışavurumsal yansımaları Türkiye özelinde kesitsel bir tarih aralığı üzerinden benzer işlevi kamu adına yerine getiren çarşı ve mahalle bekçileri üzerinden incelenmek istenilmiştir.

Çarşı ve mahalle bekçilerinin uzun süre sonra yeniden alım yapıldıkları 2016 yılı başlangıç olarak kabul edilmiş ve 2020 yılına kadar gelişen süreç gözetilerek çalışmanın tarihsel çerçevesi oluşturulmuştur. İnternet üzerinden sunulan haber içerikli verilerin suç oranlarını esas alan metinleri bekçilerinin suçun önlenmesindeki sosyal rolleri dikkate alınarak analiz edilmiş, Türkiye özelinde uygulamada eşleniği olduğu değerlendirilen bekçilerin sosyal rolünün yansımaları incelenmiştir.

Çalışmada yer verilen ve haber sitelerinin paylaşımlarında belirtilen tarih aralığ üzerinden (2016-2020) detaylı veriye ulaşılabilmesi için farklı zaman dilimlerinde yeniden araştırma yapılarak elde edilen verilerin çeşitliliği sağlanmaya çalışılmıştır. Bahse konu anahtar kelimeler üzerinden yapılan araştırmada bekçilerin suçun önlenmesi kapsamında rolleri değerlendirilerek araştırma soruları ulaşılan tema ve kategoriler bağlamında yorumlanmıştır.

\section{Araştırmanın Bulguları}

Araştırma kapsamında haber siteleri üzerinden taraması yapılan "Çarşı ve Mahalle Bekçisi", "Suç İstatistikleri" ve "Suç Önleme" anahtar kelimeleri üzerinden ulaşılan haber kaynaklarının anlam ve ifade özlerine dokunulmaksızın, araştırma soru cümleleri çerçevesinde tema ve kategorilerin oluşturulmasına özen gösterilmiştir.

\subsection{Yazılı Dokümanlarda Vurgulanan Kavramlar}

Topluma ve bireye bilgi verme işlevinden sorumlu medya kurumlarının internet siteleri üzerinden paylaştıkları haber içerikleri suç önleme faaliyetleri başlığı altında içerik analizine tabi 
tutulmuştur. Tablo 1'de belirtilen "Yazılı Dokümanlarda çarşı ve mahalle bekçilerinin sosyal rolüne ilişkin vurgulanan kavramlar nelerdir?" sorusu kapsamında elde edilen içerikler aşağıda ulaşılan kategorilere göre sıralanmıştır:

“...81 il emniyet müdürlüğü kadrosundaki 21 bin 723 bekçi, geceleri yaya devriye göreviyle suçun önlenmesi, şüphelilerinin yakalanması ve sorumluluk alanına giren bölgelerde asayişin să̆lanmasında etkin görev yapıyor...” (Anadolu Ajansı, 09.03.2020; Asayiş Hizmeti, Yaya Devriye)

“...Çarşı ve mahalle bekçileri, geceleri yaya devriye göreviyle suçun önlenmesi, şüphelilerin yakalanması ve asayişin sağlanması için etkin bir şekilde görev yapıyor..." (Hürriyet, 26.07.2019; Asayiş Hizmeti, Yaya Devriye)

“...2016 yılında Emniyet Teşkilatı bünyesinde yeniden hayata geçirdi. 81 Il Emniyet Müdürlüğ̈̈ bünyesinde görevli 21 bin 723 Çarşı ve Mahalle Bekçisi geceleyin yaya devriye görevi gerçekleştirerek suçun önlenmesi, meydana gelen suçun şüphelilerinin yakalanmasında ve sorumluluk alanına giren bölgelerde asayişin düzenli bir şekilde sağlanmasında etkin bir şekilde görev alıyor...” (İçişleri Bakanlı̆̆l, 09.03.2020; Asayiş Hizmeti, Yaya Devriye)

“...Asayiş politikalarının uygulanması, şehirlerde çarşı ve mahalle bekçilerinin göreve başlaması, sokakta polisin ve jandarmanın görünürlüğünün artması ve ülke genelinde uygulanan eş zamanlı Güven- Huzur Uygulamaları malvarlığına karşı işlenen tüm suçları ciddi oranda azalttı..."(Haber Türk, 11.11.2018, Asayiş Hizmeti, Görünürlük, HuzurAsayiş Uygulamaları)

“...Bekçilerin, görev yaptıkları alanlarda muhtar, esnaf ve mahalle sakinleri ile kurdukları iletişimin önleyici müdahale, suçun kaynağının belirlenmesi ve bilgi edinme konularında güvenlik güçlerine fayda sağladı̆̆ tespit edildi..." (İçişleri Bakanlığı, 24.07.2019; Suç Kaynağında Bilgi Edinme)

“...Gece yaya devriye görevi icra etmeleri vatandaşlarımızın güvenlik algısını olumlu yönde etkilemiş, görev yaptıkları bölgelerde esnaf ve mahalle sakinleri ile kurdukları iletişim önleyici polislik hizmetlerinde fayda göstermiştir...” (Elâzı̆̆ Son Haber, 05.09.2019; Yaya Devriye)

“...Genel kolluk kuvvetlerinin yardımcısı pozisyonundalar. Bir kimsenin canına, malına, ırzına saldıranları önleme, suç işlendikten sonra veya suç işlenirken sanıkları suçüstü yakalama ve kamu düzenliğini bozacak birtakım eylemlere müdahale etme yetkilerine sahipler... uyuşturucu madde satılan ve kumar oynanan yerleri, gizli fuhuş yapanları, halkın istirahatini bozanları, rezalet çıkaracak derecede sarhoș olup başkalarını rahatsı edenleri kolluk kuvvetlerine haber vermek ve önlenmesi gerekenleri önlemek" (BBC News, 22.08.2017; Suç Kaynağında Bilgi Edinme)

“...Aldı̆̆ yoğun tedbirler, park ve umuma açık yerlerde görevlendirilen Çarşı ve Mahalle Bekçileri ile tüm ekiplerle şüpheli şahıs ve araçlar üzerinde yapılan uygulamalar, uyuşturucu satan ve kullananlar ile Organize Suç Örgütlerine yönelik yapılan operasyonlar suç oranlarının düşüşünde etkili olduğu görülüyor." (Ses Gazetesi, 26.07.2020; Asayiş Uygulaması).

“...Çarşı ve Mahalle Bekçileri yaya devriye göreviyle suçun önlenmesi, şüphelilerin yakalanması ve sorumluluk alanına giren bölgelerde asayişin sağlanması için etkin görev yapıyor..." (Manisa Kulis Haber, 26.07.2019; Yaya Devriye).

“...Devletin en önemli görevi ve özelliklerinden bir tanesi caydırıcı tedbirlerle suçu işlenmeden engellemek, tabiri caiz ise testi kırllmadan tedbir almaktır. Devletimizin sahadaki vatandaşların malına, ırzına, çoluğuna, çocuğuna gelecek her türlü tehdide bir gözcüsü, bir koruyucusu olarak istihdam ettiği bekçiler, suçun önlenmesinde ciddi rolü olan aktörlerdir..." (Adana Hilal, 03.06.2020; Koruma).

“...çarşı ve mahalle bekçileri geceleri yaya devriye göreviyle suçun önlenmesi, şüphelilerinin yakalanması ve sorumluluk alanına giren bölgelerde asayişin sağlanması için 


\section{etkin bir şekilde görev yapıyor..." (Türkiye Haber Merkezi, 26.07.2019; Asayiş Hizmeti,}

\section{Yaya Devriye)}

Çarş1 ve Mahalle Bekçilerinin güvenlik hizmetlerinin ifası sürecinde sosyal rollerine dair yazılı dokümanlarda geçen kategorilerinin altı başlık altında sınıflandığı tespit edilmiştir. Haber sitelerinde yer alan metin içeriklerin Tablo 1'de belirtilen çarşı ve mahalle bekçilerinin suç önleme faaliyetleriyle benzer ifadeler üzerinden izah edildiği görülmüştür. Geleneksel açıdan taşıdığı ismi devam ettirmenin yanı sıra görev tanımı açısından geçmiş dönemler ile benzer mahiyette görev yapan bekçilerin suç önleme görevleri açısından en çok vurgulanan kategorinin ise asayiş hizmetleri ve yaya devriye olduğu tespit edilmiştir.

Çarşı ve mahalle bekçilerinin görev yaptıkları fiziki alanlarda yeniden görünür olmasının somut görev tanımlarının içeriğinde yer alan yaya devriye göreviyle özdeşleştirildiği görülmüştür. Geceleri yaya vardiya görevi sürdügü belirtilen bekçilerin suçun önlenmesi için görev aldıkları özellikle ifade edilmiştir. Ayrıca güvenlik ve huzur uygulamalarında görev aldıklarına yönelik bilgi ise diğer ifade edilen kavram olarak ön plana çıkmıştır. Bu bağlamda topluma dönük bilgi verme sürecinin yoğunlukla çarşı ve mahalle bekçilerinin şekli açıdan görev tanımları üzerinden ifade edildiği anlaşılmıştır.

Şekil 2. Dokümanlarda çarşı ve mahalle bekçiliğine ilişkin vurgulanan pro-aktif kavramlar

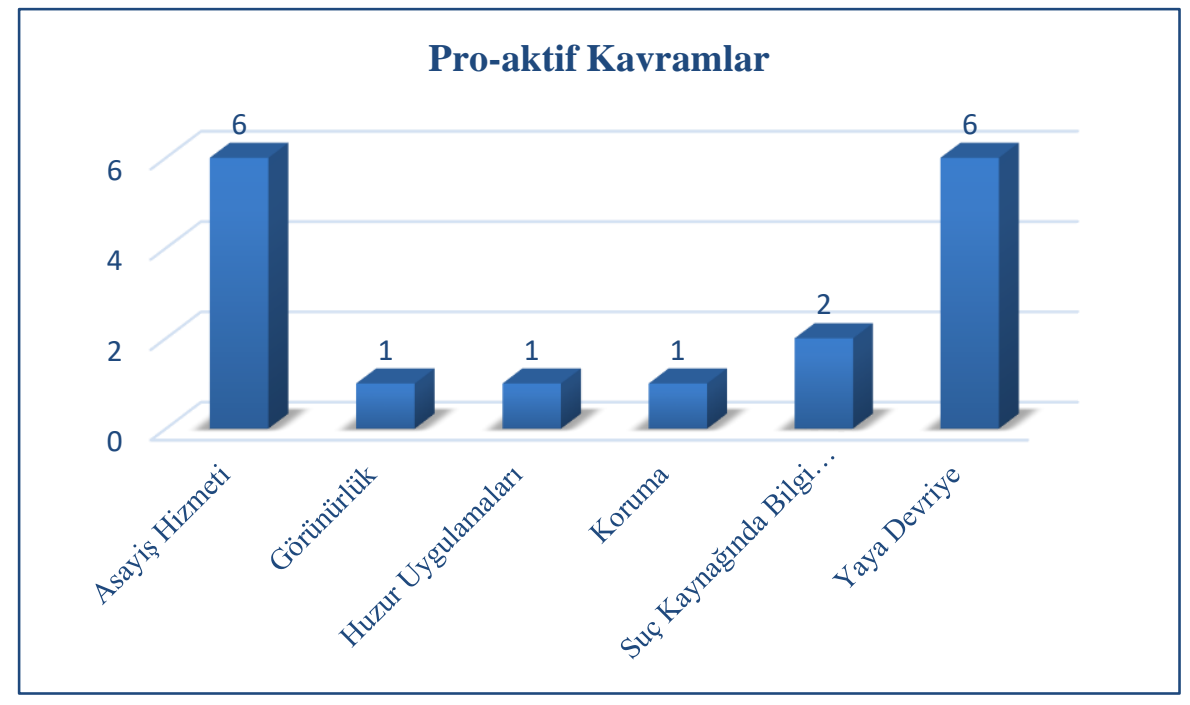

Haber sitelerinde çarşı ve mahalle bekçilerinin görev tanımlarının anlatıldığı ve içeriklerinin geneli itibariyle İçişleri Bakanlığından yapılan yazılı açıklamalara göre şekillendiği anlaşılmıştır. Yerel ölçekte Manisa, Adana, Elazığ illerinde özel açıklanalar ile bilgi verildiği görülmüştür. Ancak medya temsilleri kapsamında sunulan bilgiler içerisinde toplumun katkısı ve verdiği destek bağlamında suç oranlarına ne oranda yansıdığının ifade edilmediği anlaşılmıştır.

Asayiş hizmetleri doğrudan topluma dönük ve ilk elden gelişen suç olaylarına müdahale edilmesini esas aldığından çarşı ve mahalle bekçilerinin görünürlüğü ve sorumlu oldukları mahallerde görev almalarının caydırıcılık açısından vurgulanan bir diğer boyut olduğu görülürken, sıklıkla bu kavram üzerinde durulduğu anlaşılmıştır. Ayrıca çarşı ve mahalle bekçilerinin suçun oluşması durumunda olaya dair kaynağında bilgi edinmeleri olayların çözülmesi ve soruşturma süreçlerinin etkinliği açısından da fiziki unsurlara ek olarak suç çözümlemesini de kolaylaştıracağından dolayı güvenlik hizmetlerine katkı veren diğer kavram olarak belirtildiği anlaşılmıştır.

Savunulabilir Mekân Teorisi kapsamında mahalle sakinleri haricinde geceleyin genel kolluk kuvvetlerine yardımcı olmak üzere görev tanımları çizilen çarşı ve mahalle bekçilerinin Türkiye özelinde geleneksel tanımları üzerinden mevzuatta belirtilen geçmişe dönemlere dönük benzer görevleri ifa ettikleri ve medya temsilleri üzerinden sunumunun yapıldığı anlaşılmıştır. 
Tarihsel açıdan geçmiş dönemlerde uygulamaları olduğu bilinen ancak 2016 yılı sonrasında fiziki açıdan yeniden mahallerde görev alan bekçilerinin görev tanımlarını ve suç önlenmesine dönük katkılarının haber siteleri üzerinden Şekil 2'de belirtilen kavramlar aracılığıyla birçok kez aktarıldığ1 görülmüsşür. Öte yandan somut olaylar üzerinden toplumsal dayanışmanın ve sosyal birlikteliğinin artmasına katkı sağlayan, yerel sakinler tarafindan destek verilerek önlenen suç olaylarının ne oranda azalma gösterdiği ve toplumsal yansımaların suç oranlarına katkısına dair sağlıklı bir bilgiye ulaşılamamıştır.

\section{2. Çarşı ve Mahalle Bekçileri Tarafından Müdahale Edilen ve Önlenen Suçlar}

Medya kurumlarının haber siteleri üzerinden paylaştıkları haber içerikleri müdahale edilen ve önlenen suçlar başlığı altında incelenmiş, Tablo 1'de belirtilen "Çarşı ve mahalle bekçilerinin hangi suçları önlemede öne çıtı̆̆g görülmektedir?” sorusu kapsamında elde edilen içerikler aşağıda kategoriler halinde sıralanmıştır:

“...Mal varlı̆̆ına karşı işlenen tüm suçlar 2019'da 2018'e göre yüzde 10, evden hırsızlık olayları ise yüzde 16,7 azaldı... Mal varlığına karşı işlenen suçların aydınlatılması oranı Ocak 2018'de yüzde 41,3 iken, Şubat 2020 itibarlyla yüzde 50,1 seviyesine yükseldi." (Anadolu Ajansı, 09.03.2020, Malvarlığına Karşı İşlenen Suçlar)

“...Geçen yılın ilk 6 ayı ile bu yılın ilk 6 ayı kıyasladığında; mal varlı̆̆ına karşı işlenen suçlarda yüzde 10'luk düşüş, olayların aydınlatma oranlarında ise yüzde 3,3'lük artış

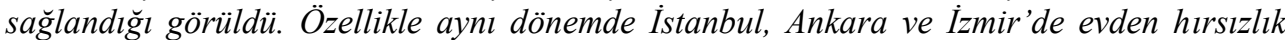
olaylarında günlük ortalama olay sayısındaki düşüs ise yüzde 16'yı buldu..." (Hürriyet, 26.07.2019, Malvarlığına Karşı İşlenen Suçlar)

“...motorize ve yaya devriye ekiplerinin sayllarının güçlendirilip sokakta polisin görünürlügünün arttırllması ile birlikte mal varlığına karşı işlenen tüm suçlarda ciddi oranda düşüşs oldu. Buna göre; mal varlığına karşı işlenen tüm suçlarda 2018 yılı ile 2019 yılı karşılaştırıldığında yüzde 10 'luk düşüs yaşanırken evden hırsızlık olaylarında bu düşüş yüzde 16,7 oldu...” (İçişleri Bakanlığı, 09.03.2020; Malvarlığına Karşı İşlenen Suçlar)

“...Hırsızlık, yankesicilik, oto hırsızlı̆̆l, yă̆ma, kapkaç gibi mal varlı̆̆ına karşı yoğun işlenen asayiş suçlarında bu yılın 10 ayında yüzde 25,5'lik azalma sağlandı. Ayrıca 2017 yılının 10 ayılık döneminde mal varlı̆̆ına karşı işlenen tüm olayların aydınlatma oranları yüzde 38 iken, bu yıl bu oran yüzde 6 artış göstererek yüzde 44'e ulaştı..." (Haber Türk, 11.11.2018, Malvarlığına Karşı İşıenen Suçlar)

“...Mal varlı̆̆ına karşı suç işleyen 643 kişiye müdahale eden bekçiler, yapılan uygulama ve sorgulama sonucu 52 bin 849 aranan kişiyi yakaladı. Bekçiler, ayrıca kişilere karşı işlenen suçlarda 114, millete ve devlete karşı işlenen suçlarda 233, topluma karşı işlenen suçlarda 4 bin 60, takibi gereken olaylarla ilgili ise 265 kişiye müdahale etti." (İçişleri Bakanlığı, 24.07.2019; Malvarlığına Karşı İşıenen Suçlar, Kişilere Karşı İşıenen Suçlar, Millete ve Devlete Karşı İşlenen Suçlar, Topluma Karşı İşlenen Suçlar)

“...Il Emniyet Müdürlüğü tarafindan yapılan açıklamada, “01 Mart 2019 tarihinden itibaren göreve başlayan Çarşı ve Mahalle Bekçileri, asayiş olaylarının yoğun olduğu mahallelerde görevlendirilerek, Mala ve Kişilere Karşı Işslenen Suçlarla Mücadelede büyük katkı sağlamıştır. " (Elazığ Son Haber, 05.09.2019; Malvarlığına Karşı İşlenen Suçlar, Kişilere Karşı İşlenen Suçlar)

“...bekçilerin göreve başladıkları tarihten bugüne 6 aylık süreçte bir önceki yıl ile yapılan kıyaslamada Kişilere Karşı İ̧slenen Suçlar yüzde 4,1, Mal Varlığına Karşı İşlenen Suçlar ise yüzde 17,8 oranında azalma gösterdiği ögrenildi... ” (Elazı̆̆ Günışı̆̆ı Gazetesi, 05.09.2019; Malvarlığına Karşı İşlenen Suçlar, Kişilere Karşı İşlenen Suçlar)

“...Aydın'ın Nazilli ilçesinde 2019 yılı ile 2020 yılı aynı dönemler karşılaştırıldığında Evden Hırsızlık olaylarında yüzde 38, İs yerinden hırsızlık olaylarında yüzde 50, Otodan Hırsızlık olaylarında yüzde 40, Açıktan Hırsızlık olaylarında ise yüzde 25 oranında azalış görüldü..." (Ses Gazetesi, 26.07.2020; Malvarlığına Karşı İşlenen Suçlar) 
“...Çarşı ve Mahalle Bekçilerinin göreve başlamasından sonra hırsızlık başta olmak üzere malvarlığına karşı işlenen suçlarda 2019'un ilk 6 ayında geçen yılın aynı dönemine göre yüzde 10 düştü...” (Manisa Kulis Haber, 26.07.2019; Malvarlığına Karşı İşlenen Suçlar)

“...Bekçilerin yeniden göreve başlamasl ve şehirlerde alınan güvenlik tedbirleri meyvesini verdi. Hırsızlık, yankesicilik, oto hırsızlı̆̆l, yă̆ma, kapkaç gibi mal varlı̆̆ına karşı yoğun işlenen asayiş suçlarında bu yılın 11 ayında yüzde 25.6'lık düşüş yaşandı...” (Sputnik, 04.12.2018; Malvarlığına Karşı İşlenen Suçlar)

“...Hırsızlık başta olmak üzere mal varlığına karşı işlenen suçlarda 2019'un ilk 6 ayında geçen yılın aynı dönemine göre yüzde 10 düştü...” (Türkiye Haber Merkezi, 26.07.2019; Malvarlığına Karşı İşlenen Suçlar)

“...Elazığ'da 6 ay önce görev başlayan çarşı ve mahalle bekçileri kentte mal varlı̆̆ına karşı işlenen suçlarl yüzde 17,8, kişilere karşı işlenen suçları ise yüzde 4,1 oranında düşürdü.”

(Time Türk, 05.09.2019; Malvarlığına Karşı İşlenen Suçlar)

Bekçilerin müdahale ettikleri suç türleri incelendiğinde öne çıkan suç kategorisinin malvarlığına karşı işlenen suçlar olduğu ${ }^{4}$ görülmüştür. Mekân ve suç bağlamında sunulan yaklaşımların özellikle mülkiyet kavramı üzerinden yoğun oranda tanımlandığ 1 tespit edilmiştir.

Şekil 3. Çarşı ve mahalle bekçileri tarafından müdahale edilen suç türleri

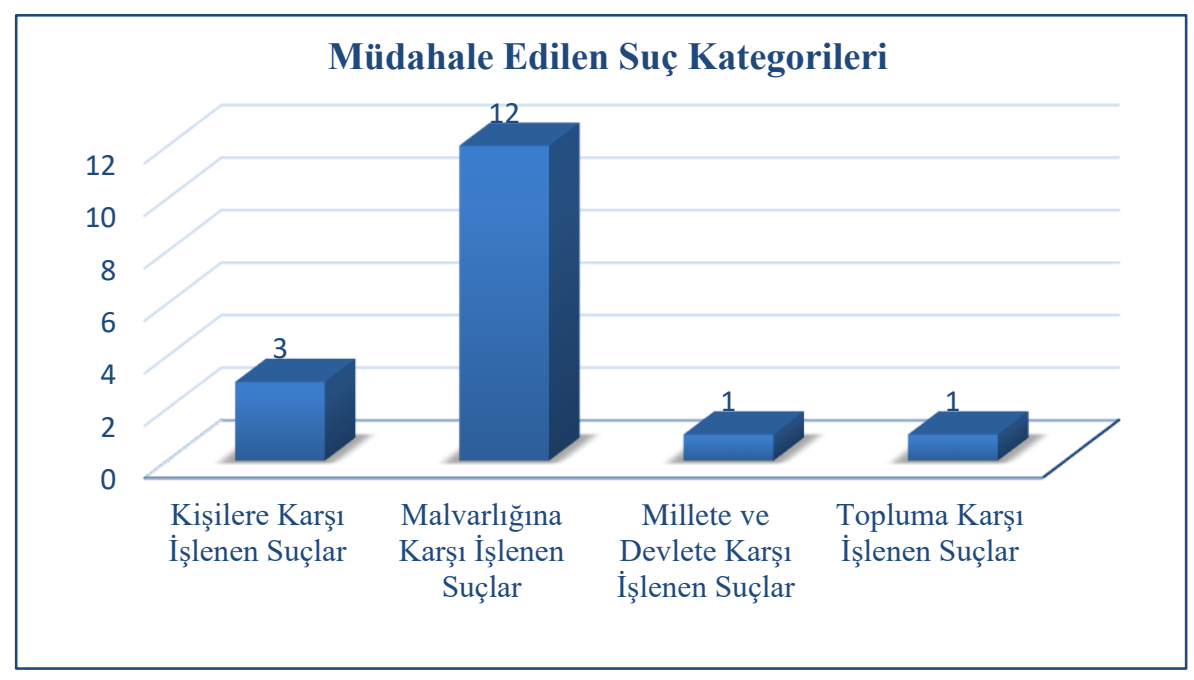

Çarşı ve mahalle bekçilerinin malvarlığına karşı işlenen suçların azalmasına katkı sağladığı ifade edilmiş ve yılın belirli dönemleri arasında suç oranlarında yaşanan düşüşlerde bekçilerin faydası haber içeriklerinde görülmüştür. Çarşı ve mahalle bekçilerinin sorumlu oldukları görev tanımları dâhilinde suç olaylarının azalmasında sunulan gerekçelerde bekçilere intikal eden olayların mahalle sakinleri tarafindan bildirilen ihbar, şikâyet gibi bilgi edinme mekanizmaların katkısına dair veri elde edilememiştir.

Bu bağlamda suçun önlenmesi açısından mikro ölçekli yerleşim yerleri özelinde toplum desteği bakış açısının yeteri kadar yazılı dokümanlarda ifade edilmediği görülmüştür. Toplumsal açından kişinin sorumluluğu altında yer almasının yanında kamu tarafından korunan, birey ile mülkiyet arasında bulunan fayda yükümlülüğünün ortadan kalkması sonucu gerçekleşen malvarlığına karşı işlenen suçların çarşı ve mahalle bekçilerinin müdahale ettiği suçlar arasında en belirgin kategori olduğu tespit edilmiştir.

\footnotetext{
${ }^{4}$ Malvarlığına karşı suçlar 5237 sayılı Türk Ceza Kanunu'nda yer verilen kişilere karşı suçlar başlı̆ı̆ altında suç türlerine ilişkin sınıflandırmalarından biridir. Medya temsillerinde sunulan metinlerin içerisindeki kullanımlarında iki farklı suç türü olarak nitelendirilmiştir, halbuki malvarlığına karşı suçlar kişilere karşı suçlar altında yer alan bir sınıflandırmadır. Metinlerde çarşı ve mahalle bekçilerin müdahale ettiği suç türlerine ilişkin sunulan kavramlar üzerinden kategoriler oluşturulmuştur.
} 


\section{3. Çarşı ve Mahalle Bekçileri Tarafından Gerçekleştirilen Faaliyetler}

Haber içeriklerinde çarşı ve mahalle bekçileri tarafindan gerçekleştirilen faaliyetler Tablo 1 'de belirtilen "Çarşı ve mahalle bekçilerince gerçekleştirilen başarll faaliyetler nelerdir?" sorusu kapsamında değerlendirilmiş, elde edilen içerikler suç öncesi yapılan idari görevler gözetilerek aşağıda belirtilen kategoriler halinde sıralanmıştır:

“...Bekçiler tarafindan 253 kilo 319 gram uyuşturucu madde, 36 bin 103 adet uyuşturucu hap, 20 uzun namlulu silah, 2 bin 321 tabanca, 876 av tüfeği, 5 el yapımı patlayıcı, 6 el bombası, 23 bin 483 mermi/av tüfeği kartuşu, 3 bin 399 kurusık tabanca, 3 bin 538 tabanca şarjörü ve muhtelif parçalar ele geçirildi...” (Anadolu Ajansı, 09.03.2020, Uyuşturucu Madde, Tabanca ve Unsurları, Patlayıcı Madde)

“...2018 yılı Eylül ayından bugüne kadar geçen sürede, çarşı ve mahalle bekçileri tarafindan 11 milyon 703 bin 894 kişi sorgulandı. 27 bin 921 kişi hakkında ise adli işlem yapıldı. Bekçiler tarafından 372 hırsızlık olayına müdahale edilirken, 870 kayıp şahıs bulundu. 313 kayıp çocuk bulunarak ailelerine teslim edildi... ”. (Hürriyet, 26.07.2019, Şahıs Sorgulama, Kayıp Şahıs)

“...253 kilo 319 gr uyuşturucu/uyarıcı (kokain, eroin, esrar, bonzai vb.) madde ile 36 bin 103 adet hap, 20 adet uzun namlulu silah, 2 bin 321 adet tabanca,876 adet av tüfeği, 5 adet el yapımı patlayıcı, 6 el bombası, 23.483 adet mermi/av tüfeği kartuşu,3 bin 399 adet kurusıkı tabanca,3 bin 538 adet tabanca şarjörü ve muhtelif parçaları ele geçirildi..." (İçişleri Bakanlığı, 09.03.2020; Uyuşturucu Madde, Tabanca ve Unsurları, Patlayıcı Madde)

“...Buna göre, İstanbul, Ankara, Antalya, Bursa, Gaziantep ve Erzurum'da, geçen yılın eylül, ekim, kasım ve aralık ile bu yılın ocak ayları arasında 6 milyon 59 bin 610 kişiye Genel Bilgi Toplama (GBT) sorgulaması yapıldı. Mal varlığına karşı suç işleyen 643 kişiye müdahale eden bekçiler, yapılan uygulama ve sorgulama sonucu 52 bin 849 aranan kişiyi yakaladı." (İçişleri Bakanlığı, 24.07.2019; Şahıs Sorgulama, Aranan Şahıs)

“...Son aylarda yakalanan çok sayıda ruhsatsız tabanca ve tüfek, patlayıcı madde, tarihi eser ve uyuşturucu madde de gözlerden kaçmadl.” (Ses Gazetesi, 26.07.2020; Uyuşturucu Madde, Tabanca ve Unsurları, Patlayıcı Madde, Tarihi Eser)

Çarşı ve mahalle bekçileri tarafından yapılan faaliyetlerin medya içerikli veriler üzerinden sunumu resmi makamların açıklamaları üzerine şekillenmiştir. Uyuşturucu madde, ateşli silah veya tabanca ile patlayıcı maddelerinin daha fazla vurgulanan faaliyetler olduğu görülmüştür. Haber kaynaklarının içeriğinin İçişleri Bakanlığının tarafından sunulan basın bültenleri kapsamında hazırlandığ 1 görülmüştür.

Şekil 4. Çarşı ve mahalle bekçileri tarafindan yapılan faaliyetler

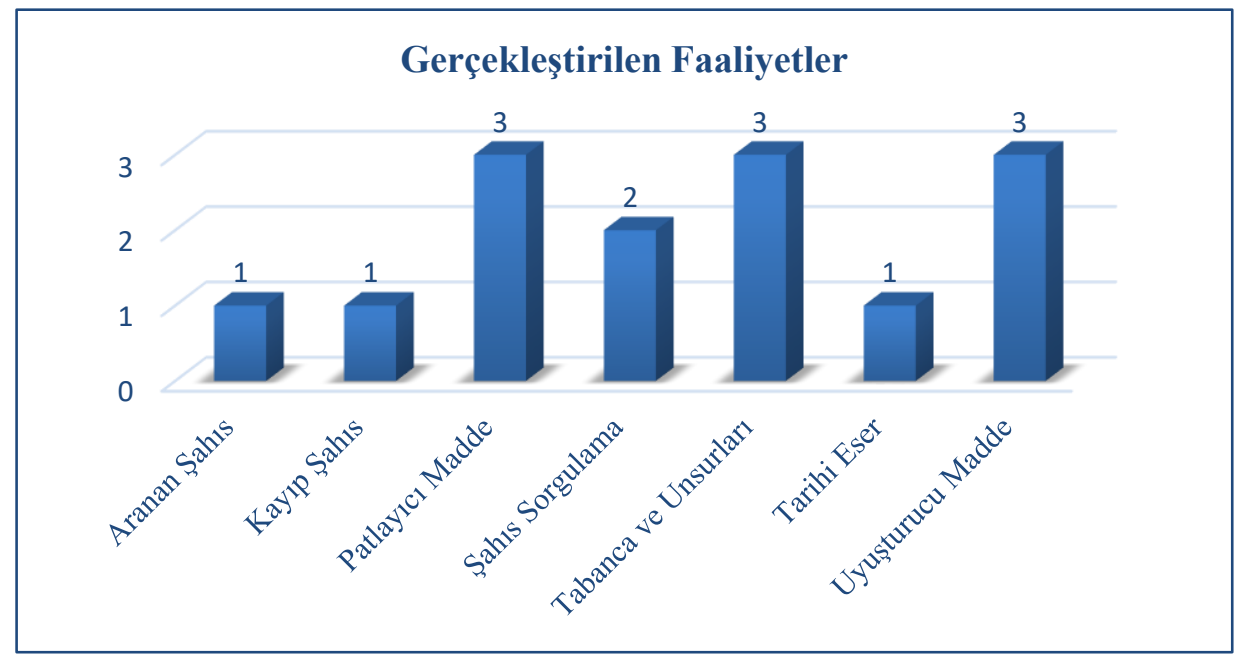


Çarşı ve mahalle bekçilerinin görevleriyle ilgili açıklamaların güvenlik hizmetlerine ilişkin görev tanımları üzerinden sunulduğu ve genel kolluk kuvvetlerinin iş tanımlarına yardımcı mahiyette görevlerden oluştuğu anlaşılmıştır. Kamu diplomasisi açısından halka dönük bu tarz bilgilendirmeler toplumun yaşam sürdüğü mekânlarda müdahale edilen faaliyet türlerinin anlaşılması bakımından fayda sağlarken, sonuçları itibariyle toplumsal iş birliğine katkı sağlaması açısından önemli birer çıktılar olarak görülmüştür.

Çarşı ve mahalle bekçileri tarafindan yapılan faaliyetler arasında genel sağlı̆̆ı olumsuz yönde etkiyen uyuşturucu madde ile kamu güvenliğini tehlikeye sokan silah ve patlayıcı maddelere ilişkin içeriklerin öne çıkan kategoriler arasında yer aldığı görülmüştür. Yapılan faaliyetler açısından diğer ifade edilen kategoriler; aranan şahıs, kayıp şahıs, şahıs sorgulama ile tarihi eser kategorileri olarak sıralandığı görülmüştür. Güncel mevzuatta suçun önlenmesine dönük görevlerin karşıllı̆ı olarak çarşı ve mahalle bekçileri tarafından gerçekleştirilen faaliyetlerin sunumunun bilinçli bir toplum inşası açısından önem teşkil edeceği değerlendirilmektedir.

\section{Tartışma}

Çarşı ve mahalle bekçilerinin geleneksel rollerinin devamı niteliğinde görülen günümüz görev tanımları medya temsillerinden elde edilen bulgular aracılığıyla değerlendirildiğinde suçun önlenmesi noktasında önemli pay sahibi olmuştur. Toplumsal alanın savunulması ve suçun önlenmesi noktasında bireye gözlem rolü düşerken, Türkiye'de kamusal ölçekte güvenlik hizmetlerinin sahaya dönük uygulamalarının yeniden bekçilerle buluşturulması suçun rasyonel çözümlenmesinde beşerî açıdan caydırıcı bir işlev sağlamıştır. Topluma bilgi verme işlevinden sorumlu medya içerikleri arasında çarşı ve mahalle bekçiliğinin caydırıcı rolü bu bağlamda en çok üzerinde durulan kavramlardan biri olduğu görülmüştür. Bu doğrultuda 2016 y1lında yeniden alımları yapılan çarşı ve mahalle bekçileri tarafindan suçun mekânda gerçekleşmeden önce önlediği ve genel suç istatistikleri bağlamında suç olaylarının azalmasında önemli rol oynadığ medya temsillerine yansımıştır.

Kanuni düzenlemelerin yanında tarihsel süreç içerisinde kanun uygulayıcı olarak görev yapan kolluk birimlerinin merkezi otorite altında toplanmasının öncesinde çarşı ve mahalle bekçiliğine benzer bir işlevi sürdüren gece bekçiliği uygulamasının yer aldığı görülmüştür. XVIII. yüzyılda güvenlik hizmetlerinin merkezi otoritelerin altında toplanması sonrasında toplum içerisinde suçla mücadele alanında suç oranlarının artış göstermesi diğer toplumlarda bir takım çevresel ve fiziki düzenlemelerin de suçun önlenmesine katkı sağlayabileceği görüşünün benimsenmesinde katkı sağlamıştır.

7245 sayılı Çarşı ve Mahalle Bekçileri Kanunu'nun görev tanımlarını düzenleyen madde hükümleri çarşı ve mahalle bekçilerine geçmiş dönem uygulamalarında yer aldığ 1 gibi önleyici bir rol vermekte, ancak anlık gelişen olaylarda da gelişen suç olayına müdahalesinde hareket kabiliyetini kolaylaştırmaktadır. İlgili mevzuat uyarınca yapılan incelemede çarşı ve mahalle bekçilerinin görev tanımlarının önceki dönemler ile benzerlik gösterdiği, bunun yanında önleyici kolluk faaliyetleri arasında yer alan durdurma ve kimlik sorma yetkisinin ise idari yönü ağır basan bir yetki olarak tanımlandığı görülmüştür. Suç önleme sürecinde hareket kabiliyetinin artırılması amacıyla düzenleme altına alınan durdurma ve kimlik sorma yetkisi ile beraber adli görevlerinin ise gecikmesinde sakınca bulunan hallerde suçla mücadele alanında katkı sağlamak üzere adli görevleri arasında sıralandığı tespit edilmiştir.

Toplumsal açıdan bilginin yaygınlaşması ve ilk elden bireye dönük haberleşme imkânı sağlaması bakımından haber sitelerinin işlevi aynı zamanda toplumsal duyarlılığ 1 artırmaktır. Çarşı ve mahalle bekçilerinin haber siteleri üzerinden yansımaları geneli itibariyle kamu kurumlarınca hazırlanan basın bültenleri çerçevesinde şekillenmiştir. Bekçilerin suç önlemeye dönük katkıları asayiş uygulamaları üzerinden makro veriler üzerinden anlatılırken, toplumsal iş birliği ve duyarlılığın gelişiminde başarılı faaliyetlerin aktarıldığı anlaşılmış, ancak toplum 
desteği sayesinde elde edilen bilgi edinme mekanizmaları vasıtasıyla çarşı ve mahalle bekçilerinin suç önleme faaliyetlerindeki rolüne dair sağ liklı bir veri elde edilememiştir.

\section{Sonuç ve Öneriler}

Mekânın iş birliği çerçevesinde suç olaylarında çözümlenmesini benimseyen yeni akım şehir planlamaları bu rolü mahalli sakinlerine ödev olarak vermektedir. Bununla beraber Türkiye özelinde bekçilik uygulamasının varlığı bu rolün mahalle sakinleriyle paylaşılmasına ve iş birliğinin sağlanmasında önemli bir beşeri unsur olarak görülmelidir. Ayrıca çarşı ve mahalle bekçilerinin sorumlu olduğu mahallelerde suç önlemeye dair başarılı faaliyetlerin belirgin bir şekilde basın bültenleri üzerinden toplumun istifadesine sunulması işlenen suçlara dönük toplumsal bilinç düzeyinin artışına katkı sağlayarak suçun önlenmesi noktasında fayda sağlayacağı öngörülmektedir.

Suç oranlarının dağılım trendlerinin yıllara göre değerlendirmesiyle birlikte yapısal özelliklerinin keşfi sonucunda mekânsal alanların korunması, birey ile mekânın inşasının bir arada değerlendirilmesi suçun önlenmesi alanında farklı bir ivme kazandıracaktır. Toplumsal sorumluluk duygusuyla mahalle sakinlerine düşen rol ise çevresine duyarlı bir birey olarak güven ilişkilerin gelişimini gözetmektedir. Böylelikle mekânın fiziksel açıdan inşa sürecinin toplumsal dayanışma olgusuyla birleşmesi suç olaylarında da beklenilen etkinin görülmesine katkı sağlayabilecektir.

Güvenlik birimlerinin takdir ettiği önemli olaylarda mikro ölçekli yerel haber sitelerinin hızlı ve etkin bir şekilde haber yapmaları toplumsal iş birliği açısından çarşı ve mahalle bekçilerinin etkinliğine katkı sağlayacaktır. Ayrıca suçun toplumsal iş birliği dâhilinde çarşı ve mahalle bekçilerine verilen destek ile çözüldüğünün saptanması ve medya temsilleri üzerinden topluma yönelik sunumu suçla mücadele alanında istenilen başarının yakalanmasında etkili olacağı değerlendirilmektedir.

\section{Kaynakça}

Adana Hilal (2020). Bekçi düdüğ̈̈, bekçiler göreve başlayınca suç oranı azaldı, https://www.adanahilal.com/haber-mhp-li-atay-bekciler-goreve-baslayinca-suc-orani-azaldi18190.html, (Erişim Tarihi: 2 Eylül 2020).

Aliağaoğlu, A. ve Uğur, A. (2016). Osmanlı şehri. Süleyman Demirel Üniversitesi Fen-Edebiyat Fakültesi Sosyal Bilimler Dergisi, (38), 203-226. Retrieved from https://dergipark.org.tr/tr/pub/sufesosbil/issue/23719/252644.

Anadolu Ajansı (2020). Bekçiler asayiş olaylarının azalmasında etkili oldu, https://www.aa.com.tr/tr/turkiye/bekciler-asayis-olaylarinin-azalmasinda-etkilioldu/1759218, (Erişim Tarihi: 1 Eylül 2020).

Anadolu Ajansı (2020). Emniyet Teşkilatı 175 yaşıında, https://www.aa.com.tr/tr/turkiye/emniyetteskilati-175-yasinda/1798184, (Erişim Tarihi: 1 Kasim 2020).

Bayramoğlu A. (2008). Osmanlı şehrinde mahalle, Sümer Kitabevi, İstanbul.

BBC News (2017). Bekçi alımı: İstanbul sokaklarına geri dönen bekçiler nasıl karşılandı, https://www.bbc.com/turkce/haberler-turkiye-41002954, (Erişim Tarihi: 2 Eylül 2020).

Beattie, J. M. (2001). Policing and Punishment in London in 1660-1750. Great Britain: Oxford University Press. p. 170-172.

Cicerali, E. ve Kaya Cicerali, L. (2018). Şehir ve güvenlik yaklaşımlarında çevresel kriminolojiye tarihsel bir bakış. İdealkent, 9 (23), 95-112. DOI: 10.31198/idealkent.417303.

Doğan, C. (2009). Eski İstanbul'da mahalle bekçisi ve 11. meşrutiyet'te bekçi teşkilatının düzenlenmesi bağlamında mahalle bekçileri nizamnamesi (1908-1918), Osmanlı Mirası Araştırmaları Dergisi, 6(14), http://dx.doi.org/10.17822/omad.2019.123. 
Donnelly, P. G. (2010). Newman, Oscar: Defensible space theory, in encyclopedia of criminological theory. sage publishing. retrieved from https://works.bepress.com/patrickdonnelly/9/.

Düzbakar, Ö. (2003). Osmanlı döneminde mahalle ve işlevleri. Uludă̆ Üniversitesi Fen-Edebiyat Fakültesi Sosyal Bilimler Dergisi, 4(5), 97-108. Retrieved from https://dergipark.org.tr/tr/pub/sosbilder/issue/23116/246910.

Elâzı ğ Son Haber (2019). Bekçiler suç oranlarını düşürdü, https://www.elazigsonhaber.com/gundem/bekciler-suc-oranlarini-dusurdu-h50319.html, (Erişim Tarihi: 2 Eylül 2020).

Gökçe A. F., Kulu, S. (2019). Çarşı mahalle bekçilerinin asayişe olan etkileri: Gaziantep ili ve Erzurum Illi Örneği, KAYFOR 17 Bildiriler Kitabı, Karaman.

Günışı̆̆1 Gazetesi (2019). Bekçiler işe başladı; suç oranı azald, https://www.gunisigigazetesi.net/elazig-guncel/bekciler-ise-basladi-suc-orani-azaldih73140.html, (Erişim Tarihi: 2 Eylül 2020).

Güven Ş. (2009), Polisin kent güvenlik uygulaması ve yönetim modeli, (Doktora tezi), Dokuz Eylül Üniversitesi Sosyal Bilimler Enstitüsü, İzmir.

Haber Türk (2018). İçişleri Bakanlığı açıkladı! Bekçilerle birlikte suç oranları düştü, https://www.haberturk.com/icisleri-bakanligi-acikladi-bekcilerle-birlikte-suc-oranlari-dustu2216326, (Erişim Tarihi: 2 Eylül 2020).

Hürriyet (2019). Bekçilerin göreve başlamasıyla hırsızlık oranları düştü, https://www.hurriyet.com.tr/gundem/bekcilerin-goreve-baslamasiyla-hirsizlik-oranlaridustu-41285232, (Erişim Tarihi: 2 Eylül 2020).

İçişleri Bakanlığı (2020). Bekçi düdüğ̈̈, asayiş olaylarının azalmasında etkin rol oynad, https://www.icisleri.gov.tr/bekci-dudugu-asayis-olaylarinin-azalmasinda-etkin-rol-oynadi, (Erişim Tarihi: 2 Eylül 2020).

Koca, T. ve Çolpan Erkan, N. (2019). Yaşam kalitesinin arttırılmasında bir etmen: Mekânsal güvenlik ölçütleri. Megaron, 14.

Manisa Kulis Haber (2019). Bekçiler geldi suç oranı düştü, https://www.manisakulishaber.com/ulusal/bekciler-geldi-suc-orani-dustu-h62973.html, (Erişim Tarihi: 2 Eylül 2020).

Mevzuat (2020). 22/07/1966 tarihli Mülga 772 sayılı çarşı ve mahalle bekçisi kanunu, (Erişim Tarihi: 29 Ağustos 2020).

Newman O., (1973). Defensible Space: people and design in the violent City, London, UK: Architectural Press.

Newman, O. (1972). Defensible Space: crime prevention through urban design. New York: Macmillan.

Newman, O. (1996). Creating Defensible Space, U.S. Department of Housing and Urban Development Office of Policy Development and Research, https://www.humanicses.com/defensible-space.pdf.

Noémi Lévy, (2008). Yakından korunan düzen: Abdülhamid devrinden ikinci meşrutiyet dönemine bekçi örneği, Osmanlı'da asayiş, suç ve ceza 18.-20. Yüzyıllar, (Der: Noémi Lévy ve Alexandre Tourmarkine), Tarih Vakfi Yurt Yayınları, İstanbul.

Plymouth Police Departmant (2007). A brief history of the plymouth, Massachusetts Police Department, https://web.archive.org/web/20070814000306/ http:// www. plymouthpolice.com, (Erişim Tarihi: 1 Kasım 2020). 
Resmî Gazete (2020). 18/06/2020 tarihli 7245 sayll çarşı ve mahalle bekçileri kanunu, (Erişim Tarihi: 29 Ağustos 2020).

Resmî Gazete (2020). Emniyet teşkilatı kanunu, devlet memurları kanunu ve genel kadro ve usulü hakkında kanun hükmünde kararnamede değişiklik yapılmasına dair kanun, https://www.resmigazete.gov.tr/eskiler/, (Erişim Tarihi:29.08.2020).

Ses Gazetesi (2019). Nazilli'de suç oranları azald, https://www.sesgazetesi.com.tr/haber/5052937/nazillide-suc-oranlari-azaldi, (Erişim Tarihi: 2 Eylül 2020).

Sputnik (2018). Bekçiler göreve başladı hırsızlık yüzde 25 azaldı, https://tr.sputniknews.com/turkiye/201812041036457106-bekciler-goreve-basladi-hirsizlikyuzde-yirmi-bes-azaldi/, (Erişim Tarihi: 2 Eylül 2020).

Thorburn, M. (2010). Reinventing the night-watchman state?. University of Toronto Law Journal, 60(2), 425-444.

Time Türk (2019). Bekçi düdüğü, bekçiler, kişi ve mal varlı̆̆ına karşı işlenen suçları düşürdü, https://www.timeturk.com/bekciler-kisi-ve-mal-varligina-karsi-islenen-suclaridusurdu/haber-1194095, (Erişim Tarihi: 2 Eylül 2020).

Türkiye Haber Merkezi (2019). Bekçiler sokaklara huzur getirdi: Suç oranı yüzde 16 düştü, https://www.turkiyehabermerkezi.com/gundem/bekciler-sokaklara-huzur-getirdi-suc-oraniyuzde-16-dustu-h262213.html, (Erişim Tarihi: 2 Eylül 2020).

\section{ETİK ve BİLIMMSEL İLKELER SORUMLULUK BEYANI}

$\mathrm{Bu}$ çalışmanın tüm hazırlanma süreçlerinde etik kurallara ve bilimsel atıf gösterme ilkelerine riayet edildiğini yazar(lar) beyan eder. Aksi bir durumun tespiti halinde Afyon Kocatepe Üniversitesi Sosyal Bilimler Dergisi'nin hiçbir sorumluluğu olmayıp, tüm sorumluluk makale yazarlarına aittir.

\section{ARAȘTIRMACILARIN MAKALEYE KATKI ORANI BEYANI}

1. yazar katk1 oran1: $\% 100$ 